\title{
The Irish Female Migrant, Silence and Family Duty in Colm Tóibín's Brooklyn
}

José Carregal-Romero

\section{(C) OpenEdition \\ 1 Journals}

\section{Electronic version}

URL: http://journals.openedition.org/etudesirlandaises/5785

DOI: 10.4000/etudesirlandaises. 5785

ISSN: 2259-8863

\section{Publisher}

Presses universitaires de Caen

\section{Printed version}

Date of publication: 18 December 2018

Number of pages: 129-141

ISBN: 978-2-7535-7693-3

ISSN: 0183-973X

\section{Electronic reference}

José Carregal-Romero, «The Irish Female Migrant, Silence and Family Duty in Colm Tóibín's Brooklyn », Études irlandaises [Online], 43-2 | 2018, Online since 01 November 2018, connection on 13

September 2019. URL : http://journals.openedition.org/etudesirlandaises/5785 ; DOI : 10.4000/ etudesirlandaises. 5785 


\title{
The Irish Female Migrant, Silence and Family Duty in Colm Tóibín's Brooklyn
}

\author{
José CARREgal-Romero \\ Universidade de Vigo
}

\begin{abstract}
Set in the 1950s, Colm Tóibín's Brooklyn (2009) traces the life experiences of Eilis Lacey, who is urged by her family to migrate to Brooklyn due to the lack of opportunities for young women in her native Enniscorthy, a small town in rural Ireland. Just as she begins to establish a new life in America, a tragic event at home calls her back to Ireland. During her visit, Eilis faces the terrible dilemma of having to choose between her sense of familial duty and the fulfillment of her own desires. In his novel, Tóibín provides a subtle and complex portrayal of the socio-familial pressures affecting the life of the protagonist, whose unverbalised thoughts speak for the decisions she is not allowed to make. In this way, Tóibín denounces the historical and cultural silences surrounding the subjectivity of the Irish female migrant.
\end{abstract}

Keywords: Colm Tóibín, Brooklyn, Ireland, migration, silence, gender and sexuality

In this analysis of Brooklyn, ${ }^{1}$ I will tackle the ways in which, both in Ireland and in the diaspora, moral obligations, gender limitations and questions of family duty often stifled Irish women's autonomy, silencing their own wishes and experiences. Unquestionably, the issue of emigration and the social expectations it entailed have proved to be a most relevant factor in Ireland. As Piaras Mac Éinri explains, between the years of the Great Famine and the 1950s, more than six million people left Ireland, a dramatic event which constituted a serious demographic anomaly, "a unique case in the world". In the first half of the twentieth century, economic and social conditions were harsh for the majority of people in Ireland and this situation did not improve after independence in 1922. Emigration was a very common phenomenon in the lives of young women. Although

1. Brooklyn was adapted into film in 2015 by John Crowley. The film became a major commercial success in the United States. According to Pat Brereton, Crowley's film "succeeded in winning audiences in the US, speaking to and for the deeply held emotions of a diasporic Irish population who have made America their home". See Brereton, Pat. "Review of Brooklyn", Estudios Irlandeses, 11, p. 285-287, 287.

2. Piaras Mac Éinri, "From Clare to Here", Études Irlandaises, 25:1, 2000. Available at [http://migration.ucc.ie/ claretext.htm] (Accessed 3 March 2014). 
national independence was "expected to signal the end of emigration through the provision of employment", the truth was that "women's employment stagnated or declined from the 1920 s to the $1980 s^{\prime}{ }^{3}$ As has been noticed, women's emigration was primarily the consequence of unemployment and the low marriage rate in the Republic, since "as soon as young Irish women realised that there was 'no husband and no job at home', they departed in greater numbers". ${ }^{4}$

Women's migration clearly contradicted the ethos of the newly independent Irish State, where nationalist groups promoted that the Irish woman's proper place was the home: "Until the 1950s at least, women's migration was variously constructed as a loss of national breeding stock, a threat to women's 'purity', and potentially undermining of their national and religious identities" ${ }^{5}$ In order to stop Irish women from migrating, the Government studied drastic measures of containment. Fintan O'Toole relates that:

At the beginning of $1995 \ldots$ State papers revealed that, in 1948, the Church and the then Government had seriously discussed the idea, put forward by the Archbishop of Tuam, of banning young women from leaving Ireland at all, so as to protect them from 'moral, national and social perils' ${ }^{6}$

Proposals such as the one mentioned by O'Toole were eventually deemed impractical in a nation where, due to widespread deprivation, many "Irish parents continued to dispatch daughters in their mid-teens to a foreign country in the expectation that their remittances would help support the family back home". Forced migration or exile thus proved to be another determinant factor in the lives of many women in mid-twentieth century Ireland for varied reasons, which include family duty, poverty or lack of marriage prospects. Additionally, many other women were also compelled to migrate due to the morally conservative nature of Irish society: "Irish women's migration throughout the twentieth century was also a response to the regulation of women's sexuality and of pregnancy outside marriage" ${ }^{8}$

Many representatives of the Church and the State continually expressed their concerns on the "moral dangers" that awaited Irish female emigrants in foreign

3. Gerardine Meaney, Mary O'Dowd and Bernardette Whelan, Reading the Irish Woman: Studies in Cultural Encounter and Exchange, 1714-1960, Liverpool, Liverpool UP, 2013, p. 106. 106.

4. Ibid., p. 95.

5. Breda Gray, Women and the Irish Diaspora, London, Routledge, 2004, p. 2.

6. Fintan O’Toole, The Ex-Isle of Erin. Dublin, New Island Books, 1996, p. 17.

7. Mary E. Daly, "Irish women and the diaspora: why they matter", in MacPherson P.A.J. and Hickman, M. J. (eds.), Women and Irish diaspora identities: Theories, Concepts and New Perspectives, Manchester, Manchester UP, 2014, p. 17-33, 18.

8. Gray, op. cit, p. 2. 
lands. However, Irish women's experiences, opinions and anxieties were often silenced. Aidan Arrowsmith draws attention to the fact that:

At the heart of the Irish emigrant experience itself there is a marked silence... This silence is particularly notable with regard to Irish women. Despite consistently outnumbering male emigrants from Ireland to England, women's voices are absent from the texts and debates surrounding the issue. ${ }^{9}$

Tellingly, as I argue here, this cultural silence surrounding the subjectivity of the female emigrant reverberates in the complex manner in which Tóibín constructs his central character in the novel, the highly observant but restrained Eilis. In fact, one of the most salient characteristics of Tóibín's narrative is the tensions between Eilis's inner reflections and her missed possibilities for self-assertion. As Tory Young rightly puts it, "the reader is privy to Eilis's feelings and is often tormented by her inability to voice them". ${ }^{10}$ Unable to assert herself, Tóibín's protagonist is "without voice"11 and "her choices can hardly be described as free". ${ }^{12}$

Among his Irish contemporaries, Tóibín is not alone in his intellectual and artistic exploration of female experiences of migration and exile. In Women and Exile in Contemporary Irish Fiction, Ellen McWilliams observes: "Whilst historically women have frequently been overlooked or made to serve an emblematic or symbolic function in the portrayal of exile in Irish writing, more recent treatments of exile and migration show a keen interest in reclaiming the history of the Irish woman emigrant and in explicitly addressing this lacuna". ${ }^{13}$ As McWilliams suggests, the topics of exile and homecoming have featured prominently in the Irish literary tradition, but not from a female viewpoint. María Amor Barros-del Río also addresses this issue in her analysis of recent Irish novels focusing women and migration, including Edna O'Brien's The Light of Evening (2006), Sebastian Barry's On Canaan's Side (2011) and Anne Enright's The Green Road (2015). Like McWilliams, Barros-del Río highlights that, in recent years, "[this] profusion of migrant fiction suggests a need to express cultural identity negotiations, a matter still unresolved, in particular those of women abroad". ${ }^{14}$

9. Aidan Arrowsmith, "M/otherlands: Literature, gender, diasporic identity", in Scott Brewster and David Alderson (eds.), Ireland in Proximity: History, Gender, Space, London, Routledge, 1999, p. 129-144, 129.

10. Tory Young, "Brooklyn as the 'untold story' of 'Eveline': Reading Joyce and Tóibín with Ricoeur." Journal of Modern Literature, 37:2, 2014, p. 123-140, 131.

11. Ibid., p. 131.

12. Ibid.

13. Ellen McWilliams, Women and Exile in Contemporary Irish Fiction, London, Routledge, 2013, 3.

14. María Amor Barros-del Río, "On Both Sides of the Atlantic: Migration, Gender, and Society in Contemporary Irish Literature." Journal of Research in Gender Studies, 6:2, 2016, p. 83-89, 85. 
Tóibín began to write his emigration novel in 2006 partly as a reaction to Irish xenophobia and the result of the 2004 Irish Citizenship Referendum, ${ }^{15}$ which removed the right to automatic citizenship to children born to immigrant parents. As Tóibín acknowledges: "Some of the impulse for [Brooklyn] is entirely political. There were times... where I felt alone in my views on immigration". ${ }^{16}$ In his writings and public lectures, Tóibín has repeatedly expressed his deep dismay at the result of this referendum, regarding it as a regressive decision that transgresses basic individual rights. In a recent interview, he declared that: "If you are born here [in Ireland] then where else could you be from other than the place where you were born? Blood, maternity, paternity -those issues are very abstract compared to 'I was born here ... that's what I know". ${ }^{17}$ According to Tóibín, citizenship laws should appropriately account for the fact that the individual's sense of belonging extends beyond questions of descent or parentage. Thus, for Tóibín, the enforcement of an exclusionary model of Irish citizenship based upon notions of bloodline can only serve to increase social divides and perpetuate racist attitudes. Curiously, in Brooklyn the protagonist's inability to build a decent future and a family life in the moralistic society of 1950 s Ireland strikingly compares to the struggle of many immigrants in a much more liberal but racist contemporary Ireland.

In Brooklyn, Tóibín presents readers with a central character, Eilis Lacey, who leads a placid existence in 1950s Enniscorthy, co. Wexford, enjoying her social life and having an easy relationship with both her mother and her sister, Rose. Unfortunately, Eilis faces a situation similar to those of young Irish people who, because of the economic crisis of the late 2000s and early 2010s, ${ }^{18}$ had to leave Ireland: "There was, at least for the moment, no work for anyone in Enniscorthy,

15. Historically, Ireland had been a country of mass emigration, and this pattern changed radically during the years of economic prosperity of the so called Celtic Tiger (1995-2008), when large numbers of workers from Eastern Europe, China and Africa were drawn to the country's prosperous economy. Xenophobic attitudes flourished in Ireland, and the so-called "non-nationals" began to be perceived as a threat to the country's well-being and prosperity. There were also stories in the media about "non-national" pregnant women expressly travelling to Ireland to give birth to their babies, who would then acquire an Irish and European citizenship. For a detailed analysis, see especially Brandi, S, "Unveiling the Ideological Construction of the 2004 Irish Citizenship Referendum: A Critical Analystical Approach.” Translocations, 2:1, 2007, p. 26-47.

16. Paul Morton, "An Interview with Colm Tóibín." Bookslut. Available at: [http://www.bookslut.com/features/2009_06_014545.php]. Accessed: 14 March, 2015.

17. Carly McLoughlin, “Images of Ireland that Matter Now’: Colm Tóibín in Conversation”, in Carmen Zamorano Llena and Billy Gray (eds.), Authority and Wisdom in the New Ireland, Bern, Peter Lang, 2016, p. 73-79, 75.

18. Ironically, Brooklyn was published in 2009, at the outset of another major economic crisis in Ireland, which led to the departure of a new generation of Irish migrants. A recent report states that "in the wake of the collapse of the Irish banking system in 2008 and the subsequent economic crisis, emigration rose substantially. The number of Irish people leaving more than tripled between 2008 and 2012." See Irial Glynn, Tomás Kelly and Piaras Mac Éinri, The Re-Emergence of Migration from Ireland, Dublin, Migration Policy Institute, 2015, 5. Available at: [https://www.migrationpolicy.org/research/reemergence-emigration-ireland-new-trends-oldstory]. Accessed 5 July 2018. 
no matter what their qualifications" ${ }^{19}$ Eilis only finds employment as a part-time shop assistant, working for the exploitative and fastidious Miss Kelly, who keeps a servant, Mary, whom she treats with contempt. Understandably, Rose, Eilis's sister, is worried and comments that: "[Miss Kelly] has a little slave, doesn't she? She took her out of a convent" (15). With no family connections and nobody to protect her, Mary finds herself at Miss Kelly's mercy. Interestingly, Tóibín alludes here to the harsh socio-economic realities of female employment throughout the first half of twentieth century Ireland. In fact, it has been noted that the conditions in which many female shop assistants worked compared to a "system of slavery". 20

At home, Eilis shares stories of her "weekly humiliation at Miss Kelly's hands" (24), but little does she suspect that this prompts Rose to secretly arrange her settlement in New York with the help of Father Flood, an Irish priest on his holidays from America. Symptomatically, nobody asks Eilis whether she wants to leave Ireland. Commenting precisely on the issue of Eilis's powerlessness, Young takes the view that the protagonist's "behavior is bound by assumed conventions." 21 When comparing Joyce's "Eveline" (1904) and Tóibín's Brooklyn, Young calls attention to the two young women's role as daughters in a patriarchal society:

Eveline and Eilis are alike in pondering over decisions, or the inability to make them. This is unsurprising: as young, unmarried women in Ireland, even fifty years apart, a lifetime of obeying parental rule meant that they had no experience of taking responsibility. When considering their departures, Eveline and Eilis are good at thinking about staying in the world they know, and less good at imagining the untold story of their future. $^{22}$

Though I agree with Young, I would also suggest that Tóibín's protagonist (and Joyce's, as well) is simply not expected to make such decisions in the first place. ${ }^{23}$ Early in the text, we learn that Eilis had once the intention to migrate to England, but her mother had rejected her idea outright. When Father Flood visits the family, he does not address himself to Eilis, but to her mother. On seeing her mother's positive response, Eilis discovers that the plans for her migration will go ahead: "Her mother had been so opposed to her going to England that this new realization came to Eilis as a shock" (23). Tóibín, then, shows how Eilis's familial

19. Colm Tóibín, Brooklyn, London, Penguin, 2009, p. 11. Further page references occur in the main text.

20. Meaney, O’Dowd and Whelan, op. cit., p. 97.

21. Young, op. cit., p. 138.

22. Ibid., p. 133.

23. For another comparative analysis between Joyce's 'Eveline' and Tóibín's Brooklyn, see Carregal Romero and Caneda Cabrera, "Female Mobility in James Joyce's 'Eveline' and Colm Tóibín's Brooklyn.” Papers on Joyce 19/20, 2013-2014, p. 55-74. 
role connects with her lack of authority to assert her own will, which leads her to remain silent about her own wishes: "She would have given anything to be able to say plainly that she did not want to go, that Rose can go instead, that she would happily stay here" (31). As Laura Elena Savu succinctly explains, "in Brooklyn, as in Tóibín's other novels, intimations of attachment are strongly felt but rarely spoken... Much of the action, in fact, takes place below the surface, in the resonance of tone, gesture, and silence". ${ }^{24}$

Equally relevant to Eilis's self-suppression is the family dynamics of silence, caused by the death of the father and the emigration of the three brothers. In his analysis, Eibhear Walshe puts forward the idea that "one of the central elements in the novel is the repressed and unspoken emotional life of the Lacey family, depleted by death and exile, and this habit of silence, inherited by Eilis, haunts the most important decisions of her life". ${ }^{25}$ Since the brothers live now in England, the two sisters and their mother had already endured the pain of losing family to emigration. Liam Mcllvanny suggests here a link between the social and personal silences pervading the Irish experience of emigration:

For much of the history of the Irish state, emigration was a national embarrassment, something it was difficult to talk about. This was equally true, Tóibín's novel suggests, at the level of the family. Eilis Lacey is leaving, perhaps for good, but her mother and sister can't talk to her about it. ${ }^{26}$

Eilis remembers that, in the days before her youngest brother departed for England, "they would do anything to distract themselves from the thought that they were losing him" (28). The same silence surrounds Eilis's imminent emigration. Along with this silence comes the resignation that, after all, emigration "was part of the life the town" (24). Thus, significantly, Tóibín does not present his character's future emigration to New York as an act of freedom or emancipation. Instead, her departure is viewed as an almost inevitable situation that brings enforced displacement.

Once she is in New York, Eilis is placed under the care of the Irish diasporic community, strongly characterised by its parochialism and norms of female respectability. Here, Tóibín — who seems to have carried out extensive research into 1940s and 1950s Brooklyn and the Irish diaspora-reproduces a detailed account of what life might have been like for a young Irish woman at that time. In her study of Irish immigration to 1950s New York, historian Linda

24. Laura Elena Savu, "The Ties that Bind: A Portrait of the Irish Immigrant as a Young Woman in Colm Tóibín's Brooklyn." PLL: Papers on Language \& Literature 49:3, 2013, p. 250-272, 255.

25. Eibhear Walshe, A Different Story: the Writings of Colm Tóibin, Sallins, Irish Academic Press, 2013, p. 131.

26. Liam Mcllvanny, "The Coldest Place on Earth." London Review of Books 31:12, 2009. Available at: [https:// www.lrb.co.uk/v31/n12/liam-mcilvanney/the-coldest-place-on-earth]. Accessed: 23 May 2017. 
Dowling Almeida notes that Irish migrants entered "established and maturing ethnic communities and in some way needed the existing community to facilitate their transition to America". ${ }^{27}$ Almeida further remarks that "family, church, and ethnic organizations dominated community life among the Irish... The parish to which one belonged typically defined social and neighborhood boundaries". ${ }^{28}$ This type of community life had a greater impact on the experiences of young unmarried women. Though the diasporic Irish community grants a sense of both security and identity, it can eventually limit the individual's desires for self-invention and autonomy. As Breda Gray has also argued, even though migration entailed an element of romanticism and individual freedom, "there is some evidence that Irish migrant women's experiences were also dominated by the cult of domesticity and Catholic Church efforts in their countries of destination to prevent the development of individualism and the occupation of the sexual self". ${ }^{29}$

Even if Tóibín does not portray the Irish community as being blatantly oppressive, clear norms of behaviour exist for young women like Eilis. As soon as the protagonist arrives, Father Flood finds lodgings for her at Mrs Kehoe's, an "Irish place" (193), where she lives with other women either from Ireland or descendants of Irish immigrants. Within the four walls of this Irish home in Brooklyn, the pious and self-righteous Mrs Kehoe acts as the guardian of strict standards of female decency and the so-called "Irish manners". In one of their dinners, she makes it clear how her lodgers should behave: "She did not like the girls talking among themselves, or discussing matters she knew nothing about, and she did not encourage any mention of boyfriends" (54).

Another figure of great importance for Eilis is Father Flood, who not only sponsors her migration and secures her a job as a shop assistant, but also enrolls her in night classes in accountancy at Brooklyn College. Interestingly, even though Tóibín characterises the priest as truly benevolent, he also portrays him as exerting great control on Eilis's life. Grateful to the priest for all his guidance, the protagonist cannot avoid asking him why he is being so generous. Father Flood's response- "we need Irish girls in Brooklyn" (78)—certainly adds some ambivalence to the apparently altruistic nature of his actions. Hence, whilst receiving the genuine kindness of the priest, Eilis is at the same time "position[ed] as an object of exchange between cultures". ${ }^{30}$ As a young woman living in the diaspora, she is expected to adapt to the moulds of her Irish Catholic background.

27. Linda Dowling Almeida, Irish Immigrants in New York City, 1945-1995, Bloomington and Indianapolis, Indiana UP, 2001, p. 4.

28. Ibid., p. 37.

29. Gray, op. cit, 28.

30. Claire Bracken, "Review of Brooklyn." Estudios Irlandeses 5, 2010, p 166-167, 167. 
In her analysis of female migration in contemporary Irish novels, Barros-del Río notes that the "social networks of Irish migrants abroad functioned as active social forces that framed their limited scope of agency. Consequently, these novels witness the pressure exerted upon the female migrants as ineluctable forces that molded their position in the new society" ${ }^{31}$ What is relevant about Tóibín's character is that, through her strategic use of silence, she manages to evade some of values and moral codes of her diasporic community. For example, at the Irish dancehall-where Irish women are expected to dance with Irish men-Eilis meets the Italian Tony, with whom she starts a relationship. Aware of the racist attitudes of some of her roommates, ${ }^{32}$ Eilis maintains a self-protective silence about Tony at the beginning of their relationship. Later on, when Eilis's boyfriend is introduced to Mrs Kehoe, he knows that he has to put on his best manners and pretend to be Irish. Tony's ploy certainly succeeds, since Mrs Kehoe will consider him a proper suitor for Eilis, "with nice old-fashioned Irish manners" (135). Eilis's landlady, who worries about Italians going to Irish dancehalls and spreading "immorality" (104), becomes easily fooled by Tony's performance. In short, Tóibín ironically brings to light the inconsistencies of fixed ideas on what it means to be Irish, as Mrs Kehoe's prejudices are mocked.

Yet, Brooklyn also shows that, at the time, a woman's personal independence was often threatened by familial obligations. After the sudden death of Rose, "Eilis's mother wrote and mentioned how lonely she was and how long the day was and how long the night" (191). Mrs Kehoe also expresses her compassion for Eilis's "poor mother" (175) and the protagonist's brother, Jack, writes a letter to urge her to travel to Enniscorthy to be with her: "I know she'd love to see you, she keeps saying that is the only thing she is hoping for... I think she wants you to come home" (180). Due to her grief and social pressures, Eilis's appreciation of her time away from her family drastically changes: "It changed everything Eilis thought about her time in Brooklyn; it made everything that had happened to her seem small” (177). As Costello-Sullivan aptly argues, Eilis is manipulated by her family and thus "reverts to familial patterns, the pull of the space she traditionally holds in her family and culture proving too strong to resist". ${ }^{33}$ This traditional space for a woman like Eilis means that she is morally obliged to disrupt her life abroad and take care of her lonely mother in Ireland. This type of familial behaviour was characteristic of traditional rural life in Ireland, when one of the daughters was always "pressurised to stay and care for an ailing parent". ${ }^{34}$

31. Barros-del Río, op. cit., 87.

32. For instance, the racist Miss McAdam readily complains that she "didn't come all the way to America, thank you, to hear people talking Italian on the street or see them wearing funny hats" (56).

33. Kathleen Costello-Sullivan, Mother/Country: Politics of the Personal in the Fiction of Colm Tóibin, Bern, Peter Lang, 2012, p. 214.

34. Jenny Beale, Women in Ireland: Voices of Change, London, MacMillan, 1986, p. 33. 
Thus, the tragic news of Rose's death provokes in Eilis a moral dilemma, as she now has to choose between her planned future in Brooklyn and her familial obligations towards her mother in Enniscorthy. When Eilis shares with Tony the content of Jack's letter urging her to travel to Ireland, she becomes convinced that she "had made [Tony] see where her duty lay" (183). Tóibín characterises Eilis through her typical indecisiveness as she faces her dilemma: she is sure that she would like to stay with Tony, but she then reasons that the letter "made plain to him that she belonged somewhere else, a place that he could never know" (184). Because he senses that they will break up, Tony demonstrates his grief openly, and this, in turn, helps Eilis reach for him and express her need for emotional closeness. This situation leads to their first sexual relationship, as Eilis invites Tony to spend the night together in her room at Mrs Kehoe's. Surprised by her "unspeakable" transgression, Eilis ponders: "In all the outrages that could be committed by the lodgers, this had never been mentioned as a possibility by the lodgers themselves or by Mrs Kehoe. It was in the realm of the unthinkable" (187-188).

Interestingly, though this diasporic community has its strict rules of female behaviour, Eilis-Mrs Kehoe's favourite lodger because of her "manners" (99)— defies social expectations by dating an Italian and having premarital sex with him in her own bedroom. Despite the readings that consider Tóibín's protagonist as being utterly passive, or a "spectator in her own life", ${ }^{35}$ I would argue that the writer constructs a much more complex character. Eilis is, thus, presented as a young woman who at times employs tactics of silence and concealment while allowing herself some autonomy away from the expectations of others.

Nonetheless, as Tóibín is careful to show in his fiction, his protagonists are always tied to their time, place and personal history. Tóibín's characters often have a rich inner life, but public factors influence them irremediably, affecting their decisions and self-image. Before she departs for Enniscorthy to visit her mother, Tony persuades Eilis to secretly marry him as a means of securing her return to America. According to Dilek Inan, the protagonist submits to Tony's wish because "she does not have a strong sense of herself, but she has a strong sense of what others make of her" ${ }^{36}$ Though Inan's argument remarks the actual fact that Eilis is constantly manipulated by others, I would also argue here that her strong attachment to Tony cannot be ignored, nor her sexual inexperience and her fear of being pregnant. Before Tony proposes, marriage is also mentioned by a priest when Eilis goes to confession: "What had happened between her and Tony... was maybe a sign from God that they should consider getting married and raising a family" (191). Marriage is thus seen as the means to make up for the "sin" of their premarital sexual rela-

35. Bracken, op. cit, p. 166.

36. Dilek Inan, “Colm Tóibín's Brooklyn: Caught Between Home and Exile." Philologist: Journal of Language, Literary and Cultural Studies 5, 2012, p. 96-104, 101. 
tionship, a way to placate the possible danger of pregnancy and illegitimate motherhood. Hence, I would argue that it is not only Tony's persuasion that drives Eilis to a hasty marriage, but also the sexual morality of her time.

Newly arrived in Enniscorthy on her visit, Eilis finds herself strangely distanced from her mother. She laments that, in all those days, "her mother had not asked her one question about her time in America, or even her trip home" (204). Eilis is not encouraged to speak about her American experience, but neither is she eager to do so. Readers soon learn that, whilst Eilis does not mention Tony, the mother hides her motives of wanting Eilis to remain in Enniscorthy. Mother and daughter are, in fact, alike in being dishonest to one another. This picture attunes with Tóibín's other fictional families, fraught with secrets and obstacles to communication, with private feelings that are hard to explain and personal interests that remain unsaid.

On the occasion of a friend of Eilis's wedding, the mother subtly machinates her daughter's extended period in the town:

'When is the wedding?'

'On Saturday, 27 June.'

'But I'll be gone back,' Eilis said.

'Your mother said you'll still be there. She wrote and accepted the invitation on behalf of the two of you.' (210)

From the beginning, Eilis senses her mother's unspoken claim on her, which discourages the protagonist from breaking her silence about Tony. Another reason for her silence on Tony connects with social sensibilities and the protagonist's need to keep up with appearances. There is one moment in which Eilis's two friends, Annette and Nancy, ask her whether she has someone waiting for her in New York. Eilis decides not to speak about Tony, as her friends would ask her about the circumstances of their engagement: "They would respond with silence and bewilderment. It would seem too strange" (211).

What is also true is that Eilis does not mention Tony because of her newly found illusions of remaking her life in Ireland. This situation causes much psychic strain and Eilis begins to feel "as though she were two people, one who had battled against two cold winters and hard days in Brooklyn and had fallen in love there, and the other who was her mother's daughter" (218). Her two family roles, her mother's daughter and Tony's wife, belong to two distinct spaces that cannot be brought together. Arguably, because of her cultural upbringing, Eilis still sees herself primarily in relation to her family roles. This self-perception implies moral obligations that restrict her freedom and agency.

In the course of her extended time in Enniscorthy, Eilis falls into a romantic relationship with Jim Farrell, whom the neighbours view "as a great catch" 
(234). Despite her initial reticence, Eilis lets herself be carried away by his attentions: "She smiled at the thought that she would go along with most of it. She was on her holidays and it was harmless" (223). Because of Jim's openness towards her and his desire to build a future together in the town, Eilis's appreciations rapidly change and she seriously considers staying in Ireland. To complicate matters further, Eilis's mother becomes exultant at the prospect of her daughter marrying Jim. On seeing Jim and Eilis together at Nancy's wedding, a neighbour approaches them and remarks how "delighted" Eilis's mother will be if they marry (238). Moreover, as time passes, it becomes increasingly difficult for the protagonist to mention her American marriage, as this would only bring disappointment, incomprehension and moral judgment.

No matter what new opportunities she may be given now, Eilis's independence is already compromised by her marriage to Tony, whose warm presence has now become "merely a shadow" (237). The idea of divorcing him comes to her mind, but divorce is seen as foreign and outrageous in 1950s Enniscorthy: "The only divorced people anyone in the town knew were Elizabeth Taylor and perhaps some other film stars" (236). Furthermore, when the protagonist thinks about Jim's reaction were she to tell him about Tony, she believes that "it could not be said; his response to her deception could not be imagined. She would have to go back" (242). Eilis's worst fears are confirmed when knowledge of her commitment in America reaches Enniscorthy. Acting as a guardian of "Irish propriety", Miss Kelly, the protagonist's former employer, has a private conversation with Eilis implying that she knows about the double life she is leading. Miss Kelly gloats over her victory against "immorality" when she tells the scared Eilis that "you can fool most people, but you can't fool me" (245). It is then disclosed that Miss Kelly is Mrs Kehoe's cousin, a discovery which fills Eilis with terror should her marriage with Tony be discovered in the town. In spite of the distance between the two places, Eilis cannot evade the transnational surveillance of Irish Catholic morality, personified here by both Mrs Kehoe and Miss Kelly. Therefore, in Tóibín's novel, as Eve Walsh Stoddard eloquently puts it, "the transnational linkages between Ireland in Enniscorthy and Ireland in Brooklyn turn into ties that bind, and perhaps strangle" ${ }^{37}$ Eilis has no option but to leave Enniscorthy and escape scandal.

The final scene of Brooklyn concerns Eilis's confession to her mother, when she informs her that she is married and must go back to America. Shocked by the news, the mother stays evasive and apparently indifferent to her daughter's distress, though she does reveal some of her repressed anguish: "If I say any

37. Eve Walsh Stoddard, "Home and Belonging among Irish Migrants: Transnational versus Placed Identities in The Light of Evening and Brooklyn." Eire-Ireland, 47:1\&2, 2012, p. 147-171, 154. 
more, I'll only cry" (249). As the protagonist heads towards America, she does not know what situation she will meet on her arrival. ${ }^{38}$ Eilis imagines the years ahead, when this final break with the mother and her separation from Enniscorthy "would come to mean more and more to her" (252). In her reading of the ending, Marisol Morales-Ladrón rightly notes how "both her real mother and her allegorical (mother)land will callously dispatch Eilis, incapable as they are to accommodate the uncertainties and ambiguities that have molded her" ${ }^{39}$ Eilis, as Morales-Ladrón contends, is forced to leave because of the social mores of her native Enniscorthy. In fact, the protagonist's last actions in the novel are propelled by sentiments of fear and anxiety. With this ending, Tóibín powerfully symbolises how, at that time in Ireland, women's lives were constantly marked by the threat of social exclusion.

To conclude, if Eilis's first migration is caused by her lack of opportunities in Enniscorthy, her second one is induced by the danger inherent in a sexual scandal which could cause this young woman's stigmatisation and marginalisation. Tellingly, in both cases, the protagonist remains reluctant about her departure -thus, in the figure of Eilis, Tóibín dramatises "the failure of emigration as liberation". ${ }^{40}$ Furthermore, just as women's voices in Ireland were absent in public discussions about emigration, so is Eilis's voice in the novel when it comes to her interactions with others, as she is seldom asked about her own needs and experiences. Consequently, in Tóibín's Brooklyn, the reader is confronted with a protagonist whose experiences are shaped by a personal history of silence and self-suppression. Throughout the novel, Tóibín makes readers share his central character's insecurities, indecisions and renunciations in the face of external circumstances that reduce her options in life.

In his novel of emigration, Tóibín effectively exposes the restrictions of the limited constructions of gender, sexuality and the family in Irish society. According to the moral standards of her time, Eilis becomes a transgressor who defies the norms of "female decency". Yet, Tóibín sets these transgressions against the repressive control of a patriarchal society that seriously restricts Eilis's agency. Though the protagonist deceives her mother, Tony and Jim, Tóibín also shows how the manipulated Eilis accepts the wishes and decisions of others even if these affect her life in irrevocable ways, as demonstrated by her first migration

38. John Crowley's Brooklyn (2015) adds a final sequence in which Eilis returns to New York and reunites with a welcoming and loving Tony. Thus, whereas Tóibín's story finishes with a tone of uncertainty, Crowley's filmic adaptation opts for a happy ending. According to Brereton, Crowley's decision is understandable, as it reflects "the screen medium's demand for narrative closure". Brereton, op. cit, 286.

39. Marisol Morales-Ladrón, "Demistifying Stereotypes of the Irish Migrant Young Woman in Colm Tóibín’s Brooklyn." Revista Canaria de Estudios Ingleses, 68, 2014, p. 173-184, 180.

40. Edward A. Hagan, "Colm Tóibín's 'As Though' Reality in Mothers and Sons, Brooklyn, and The Empty Family." New Hibernia Review / Iris Éireannach Nua 16:1, 2012, p. 31-47, 42. 
to America and her marriage to Tony. Eilis leads a secret life on her return to Enniscorthy because of her necessity to explore new possibilities other than those demarcated by her moral obligations to others. Nonetheless, it is also true that, by remaining silent about her commitment to Tony, Eilis ironically conforms to her role as a dutiful daughter who fulfills her mother's expectations. In the end, her family duty to her husband prevails due to questions of social respectability and the impossibility to build a decent life in a society that would judge her transgression harshly. 